\title{
Productive profile of cattle-rearing farms in the state of Minas Gerais, Brazil, 2002
}

\section{Perfil produtivo de propriedades produtoras de bovinos do Estado de Minas Gerais, Brasil, 2002}

\author{
Cristiane de Morais ALVES'1,\$; Elaine Maria Seles DORNELES2,s; Luciana Faria de OLIVEIRA,; \\ José Soares FERREIRA NETO ${ }^{4}$; Vitor Salvador Picão GONÇALVES ${ }^{5}$; José Ricardo LÔBO ${ }^{6}$; \\ Marcos Bryan HEINEMANN ${ }^{4}$; Andrey Pereira LAGE ${ }^{7}$
}

\author{
${ }^{1}$ Ministério da Agricultura Pecuária e Abastecimento, Superintendência Federal de Agricultura, Belo Horizonte - MG, Brazil \\ ${ }^{2}$ Universidade Federal de Lavras, Departamento de Medicina Veterinária, Lavras - MG, Brazil \\ ${ }^{3}$ Instituto Mineiro de Agropecuária, Belo Horizonte - MG, Brazil \\ ${ }^{4}$ Universidade de São Paulo, Faculdade de Medicina Veterinária e Zootecnia, São Paulo - SP, Brazil \\ ${ }^{5}$ Universidade de Brasília, Faculdade de Agronomia e Medicina Veterinária, Brasília - DF, Brazil \\ ${ }^{6}$ Ministério da Agricultura Pecuária e Abastecimento, Departamento de Saúde Animal, Brasília - DF, Brazil \\ ${ }^{7}$ Universidade Federal de Minas Gerais, Escola de Veterinária, Departamento de \\ Medicina Veterinária Preventiva, Belo Horizonte - MG, Brazil
}

\begin{abstract}
A descriptive cross-sectional study was conducted in the state of Minas Gerais, Brazil, with the aim to assess aspects of cattle production. A multistage clustering model was used to select 2,202 farms in seven cattle production strata in the state, and a questionnaire was applied to obtain information related to the characterization of the farms and their management of animal reproduction and production. The study showed that livestock-rearing in Minas Gerais continues to be unspecialized. Triângulo Mineiro and North were the regions that used most technology and had highest beef cattle activity. The Zona da Mata region showed the least use of technology and had the smallest farms. Milk production in this state was distributed among all strata, but was concentrated among a few producers in the stratum of highest production, especially in the region of Alto Paranaíba. This study showed a great heterogeneity among the strata regarding the characteristics of type of exploitation, type of rearing, herd size, specialization and milk production. Thus, it validated the stratification established by the Ministério da Agricultura Pecuária e Abastecimento - MAPA (Brazilian Ministry of Agriculture, Livestock and Food Supply), thereby suggesting that these strata should be maintained for further epidemiological studies.
\end{abstract}

Keywords: Production characterization. Cattle livestock-rearing. Milk production. Beef farms.

\section{Resumo}

Com o objetivo de avaliar os aspectos da produção de bovinos no Estado de Minas Gerais, realizou-se um estudo transversal descritivo. Foram selecionadas, pelo método de conglomerados multiestágios, 2.202 propriedades distribuídas em sete estratos produtores de bovinos do estado, nas quais foram aplicados questionários visando obter informações relacionadas à caracterização da propriedade e do manejo produtivo e reprodutivo dos animais. A pecuária bovina em Minas Gerais ainda é pouco especializada, sendo a Região do Triângulo Mineiro considerada a mais tecnificada e com maior expressão na exploração de animais de corte, juntamente com a Região Norte de Minas. A Zona da Mata foi considerada a menos tecnificada e constituída pelas menores propriedades. A produção de leite no estado está distribuída por todos os estratos, no entanto é concentrada em poucos produtores das faixas de maior produção, com destaque para a Região do Alto Paranaíba. O estudo mostrou que há grande heterogeneidade entre os estratos no que se refere às características tipo de exploração, tipo de criação, tamanho de rebanho, especialização e produção de leite, validando a estratificação estabelecida pelo Ministério da Agricultura, Pecuária e Abastecimento (MAPA) e sugerindo sua manutenção em futuros estudos epidemiológicos.

Palavras-chave: Descrição produtiva. Pecuária bovina. Produção de leite. Gado de corte.

${ }^{\S}$ These authors contribute equally to this study. 
Correspondence to:

Andrey Pereira Lage

Universidade Federal de Minas Gerais

Av. Antônio Carlos, 6627, Pampulha

PO Box 567, CEP 31270-901, Belo Horizonte, MG, Brazil

Tel.: +55 3134092081

Fax: +553134092080

e-mail: alage@vet.ufmg.br

Received: 28/02/2018

Approved: 21/09/2018

\section{Introduction}

Agricultural and livestock activities have always had a fundamental role in the process of economic development in Brazil. This can be verified through the close socioeconomic connection between the rural sector and the urban sector (BANDEIRA, 2001). Defining the productive profile of cattle-rearing is an important, if not essential tool for studies on the dynamics of the agriculture and livestock-rearing sectors and for actions regarding animal development and health services.

Cattle production in the state of Minas Gerais follows Brazilian patterns, being geographically dimensioned according to specializations and types of exploitation, following social, economic and political parameters that determine the formation and reproduction of general and particular forms of livestock production. Minas Gerais, with its history in agribusiness, stands out at a national level. This state has the first and third position in the ranking for dairy and beef production, respectively (FNP, 2014). Regarding dairy activities, Minas Gerais accounted for $27.3 \%$ of the total national production (IBGE, 2011), increasing by 20.3\% between 2007 and 2011, following the national average (22.8\%).

Descriptive epidemiological studies are widely used to evaluate the disease situation of animals, contributing towards identifying potential risk factors and implementing, developing and evaluating disease control programs (NOORDHUIZEN et al., 1997). In addition, these studies also provide a detailed description of the types of existing rural properties.

In view of the scarcity of studies in the specialized literature that characterize cattle production in Brazil and especially in the state of Minas Gerais, the objective of this study was to contribute to establishing a productive profile for this important area for livestock in Brazil and validate the subdivision proposed for this state into seven strata, which were previously defined by the
Ministério da Agricultura Pecuária e Abastecimento MAPA (Brazilian Ministry of Agriculture, Livestock and Food Supply).

\section{Material and methods}

\section{Study area}

This study was conducted in the state of Minas Gerais, which is located in southeastern Brazil and is the fourth largest state in the country (IBGE, 2011), with a total area of $586,528,293 \mathrm{~km}^{2}$, distributed among 853 municipalities. Minas Gerais is the second most populous state in the country, with $20,593,356$ inhabitants and an urbanization rate of $84.5 \%$ (IBGE, 2010; 2012a).

Minas Gerais has a total of 23,965,914 cattle (IBGE, 2012 b), which represents $61.1 \%$ of the cattle herds in southeastern Brazil and $11.3 \%$ of the cattle herds in the entire national territory.

\section{Data source}

A descriptive cross-sectional study was conducted based on information stored in electronic forms using Microsoft Access 1997. These forms were kindly supplied by MAPA as part of their partnership with Departamento de Medicina Veterinária Preventiva e Saúde Animal/Faculdade de Medicina Veterinária e Zootecnia/Universidade de São Paulo (VPS/FMVZ/ USP). This information results from epidemiological surveys for bovine brucellosis in Minas Gerais, 2002 (GONÇALVES et al., 2009), as part of the actions taken within the scope of the Programa Nacional de Controle e Erradicação da Brucelose e Tuberculose Animal PNCEBT (National Program for Control and Eradication of Animal Brucellosis and Tuberculosis). To conduct this study, 2,204 farms with reproduction activity were selected among 700 municipalities in all seven strata (Figure 1), following the method of multistage clusters (GONÇALVES et al., 2009). Random sampling of farms in each stratum was performed based on the record of breeders at the local units of the Instituto Mineiro de Agropecuária - IMA (Minas Gerais State Animal Health Authority). Blood was sampled from animals on these farms to diagnose brucellosis, and questionnaires were applied by IMA technicians between February and October 2002. 


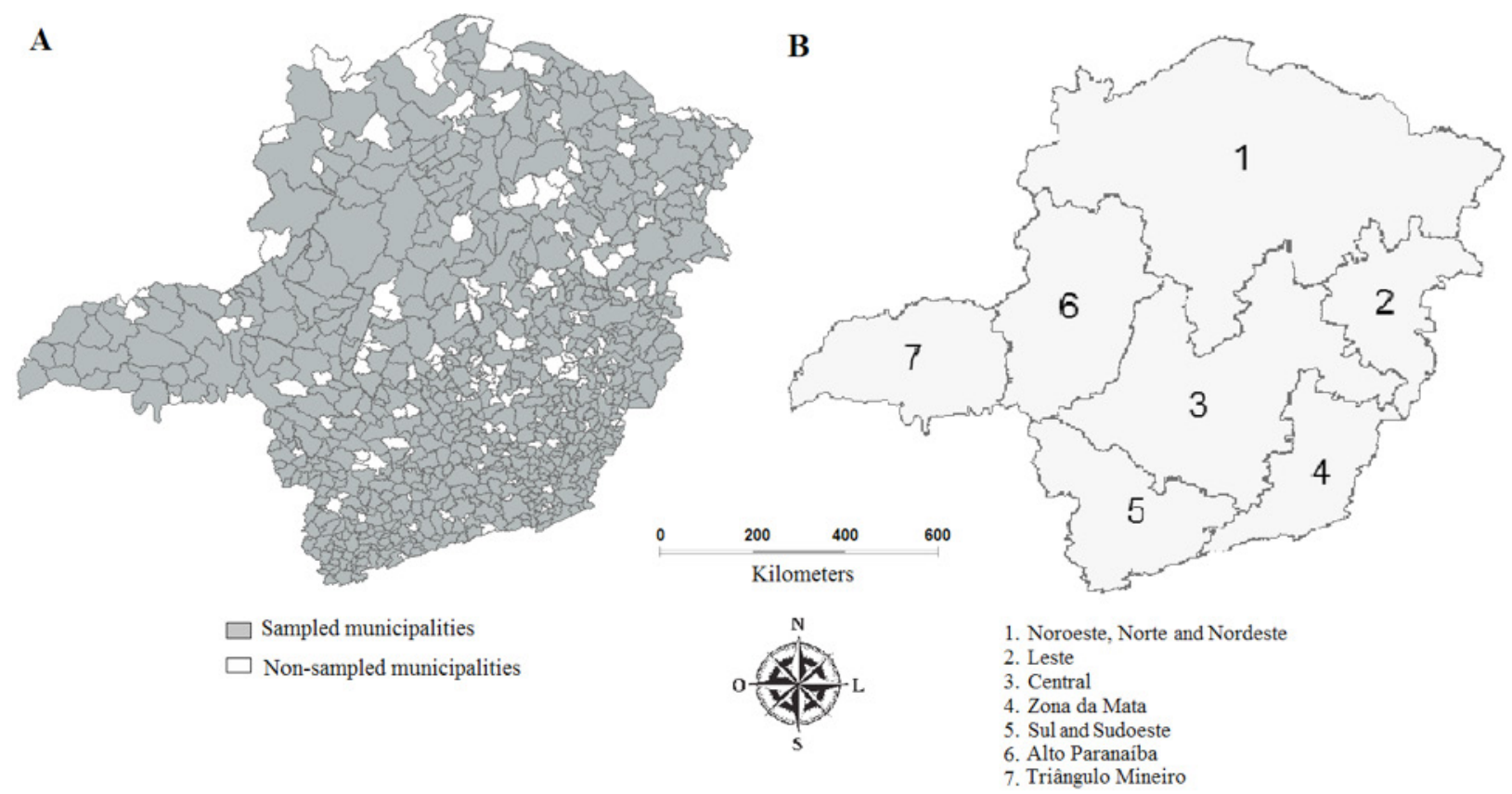

Figure 1 - Geopolitical divisions of the state of Minas Gerais showing (A) the municipalities sampled and (B) the subdivision into the seven strata used in the study

Strata were defined based on different production systems, management practices, exploitation objectives, mean herd sizes and commercialization systems. The operational and logistical capacity of the IMA to perform fieldwork was also taken into consideration, based on the areas of activity of its local units.

The numbers of farms with reproductive activity from each stratum and their respective number of sampled herds are observed in Table 1. Although the numbers of farms sampled in all seven strata were practically the same, each stratum had a different impact, due to the large variation in the number of farms available.

Table 1 - Sampling of the brucellosis survey carried out in 2002 in the state of Minas Gerais, per stratum

\begin{tabular}{cccc}
\hline Strata & $\begin{array}{c}\text { Farms with bovine } \\
\text { reproduction activity }\end{array}$ & $\begin{array}{c}\text { Number of } \\
\text { sampled herds }\end{array}$ & $\begin{array}{c}\text { Relative } \\
\text { weight }^{\mathbf{a}}\end{array}$ \\
\hline 1 & 60,547 & 318 & 0.20 \\
2 & 20,472 & 307 & 0.07 \\
3 & 73,932 & 326 & 0.25 \\
4 & 43,688 & 323 & 0.15 \\
5 & 55,602 & 316 & 0.18 \\
6 & 25,568 & 305 & 0.09 \\
7 & 20,921 & 307 & 0.07 \\
Total & $\mathbf{3 0 0 , 7 3 0}$ & $\mathbf{2 , 2 0 2}$ & - \\
\hline
\end{tabular}

${ }^{a}$ relative weight of the number of cattle in each stratum compared to the total cattle of the sampled area; Strata: 1 - Northwest, North and Northeast; 2 - East; 3 - Central; 4 - Zona da Mata; 5 - South and Southwest; 6 - Alto Paranaíba; 7 - Triângulo Mineiro

\section{Data validation}

Data were transferred from the Microsoft Access $1997^{\circ}$ software to the database of the Microsoft SQL Server $2000^{\circ}$ software with the aim to validate, consolidate and create new variables. For the analysis, 2,202 farms were sorted. Two farms were excluded because of data inconsistencies, which made analysis impossible for most variables (both fields were unfilled or were filled incorrectly).

\section{Study variables}

The questionnaire applied at the farms involved variables related both to the production profile of the cattle herds and to the sanitary conditions associated with brucellosis control. The variables of interest selected for this study were related to production characteristics. They included qualitative variables (type of exploitation; type of rearing; use of artificial insemination; kind of breed used; and type of milking) and quantitative variables (number of castrated males; number of males and females aged between 0 and 6 months, 6 and 12 months, 12 and 24 months and above 24 months; size of the herd; milk production in liters; and frequency of milking).

\section{Data analysis}

Frequencies and 95\% confidence intervals were calculated for the qualitative variables, for each stratum and for the entire state. The results for the variables for the whole state were presented based on the sampling design effect, which is the ratio between the variance obtained using the two-stage sampling method and the variance 
under the assumption of simple random sampling, taken from the same population. For example, a sampling design effect of 2.00 means that the variance is twice as large as that of a sample of the same size taken randomly (ZAR, 1999).

A descriptive statistical analysis was performed for the quantitative variables for each stratum and for the entire state. None of the variables studied presented normal distribution according to the Kolmogorov-Smirnov normality test (ZAR, 1999). Thus, the nonparametric Kruskal-Wallis test (SIEGEL, 1975) was first applied and subsequently the nonparametric multiple comparison test proposed by Dunn (ZAR, 1999), for a significance level of $5 \%$ and seven samples ( $\alpha=0.05$ and $k=7)$ (ZAR, 1999). All statistical analyses were performed using the application Stata, version $12^{\circledast}$ (Statacorp, USA).

\section{Results and discussion}

The frequencies estimated for the type of exploitation per production stratum and for the whole state are described in Table 2. Similarly to the data in the Brazilian Livestock Yearbook 2014 (FNP, 2014), the results showed that dairy exploitation was the most prevalent activity in the state of Minas Gerais (56.2\%) (Table 2). Among the dairy farms, $50.2 \%$ reared their cattle herd under an extensive system and $48.2 \%$ under a semi-confined system. Farms with mixed exploitation accounted for $33.7 \%$ in this state (Table 3 ). The extensive system was the predominant rearing system used, on $68.2 \%$ of the farms sampled. In this study, statewide participation of beef livestock-rearing was limited to $10.1 \%$ (Table 2), and on $80.8 \%$ of these farms, the animals were exclusively reared on pasture.

Table 2 - Frequency of the types of exploitation adopted in the herds sampled per stratum in the state of Minas Gerais, 2002

\begin{tabular}{|c|c|c|c|c|c|c|c|c|c|c|}
\hline \multirow{2}{*}{ Strata } & \multicolumn{3}{|c|}{ Beef } & \multicolumn{3}{|c|}{ Dairy } & \multicolumn{3}{|c|}{ Mixed } & \multirow{2}{*}{ Total } \\
\hline & $\mathbf{n}$ & $\%$ & $\mathrm{Cl}^{\mathrm{a}}(95 \%)$ & $\mathbf{n}$ & $\%$ & $\mathrm{Cl}(95 \%)$ & $\mathbf{n}$ & $\%$ & $\mathrm{Cl}(95 \%)$ & \\
\hline 1 & 79 & 24.8 & $20.3-30.0$ & 99.0 & 31.1 & $26.1-36.6$ & 140 & 44.0 & $38.5-49.7$ & 318 \\
\hline 2 & 21 & 6.9 & $4.4-10.5$ & 121.0 & 39.5 & $34.0-45.3$ & 164 & 53.6 & $47.8-59.3$ & 306 \\
\hline 3 & 19 & 5.8 & $3.6-9.1$ & 214.0 & 65.6 & $60.2-70.8$ & 93 & 28.5 & $23.8-33.8$ & 326 \\
\hline 4 & 16 & 5.0 & $3.0-8.1$ & 237.0 & 73.4 & $68.2-78.1$ & 70 & 21.7 & $17.4-26.6$ & 323 \\
\hline 5 & 10 & 3.2 & $1.6-5.9$ & 195.0 & 61.5 & $55.9-66.9$ & 112 & 35.3 & $30.1-40.9$ & 317 \\
\hline 6 & 15 & 5.0 & $2.9-8.2$ & 200.0 & 66.0 & $60.4-71.3$ & 88 & 29.0 & $24.1-34.6$ & 303 \\
\hline 7 & 64 & 20.7 & $16.4-25.7$ & 155.0 & 50.2 & $44.4-55.9$ & 90 & 29.1 & $24.2-34.6$ & 309 \\
\hline MG & 224 & $10.1^{b}$ & $8.8-11.4^{b}$ & $1,221.0$ & $56.2^{\mathrm{b}}$ & $54.1-57.4^{b}$ & 757 & $33.7^{b}$ & $31.6-35.8^{b}$ & 2,202 \\
\hline
\end{tabular}

${ }^{\mathrm{a} C o n f i d e n c e ~ i n t e r v a l ; ~}{ }^{\mathrm{b} E f f e c t}$ of sample design: 1.098. Strata: 1 - Northwest, North and Northeast; 2 - East; 3 - Central; 4 - Zona da Mata; 5 - South and Southwest; 6 - Alto Paranaíba; 7 - Triângulo Mineiro

Table 3 - Frequency of the type of rearing adopted in the herds sampled per stratum in the state of Minas Gerais, 2002

\begin{tabular}{|c|c|c|c|c|c|c|c|c|c|c|}
\hline \multirow{2}{*}{ Strata } & \multicolumn{3}{|c|}{ Confined } & \multicolumn{3}{|c|}{ Extensive } & \multicolumn{3}{|c|}{ Semi-confined } & \multirow{2}{*}{ Total } \\
\hline & $\mathbf{n}$ & $\%$ & $\mathrm{Cl}^{\mathrm{a}}(95 \%)$ & $\mathbf{n}$ & $\%$ & $\mathrm{Cl}(95 \%)$ & $\mathbf{n}$ & $\%$ & $\mathrm{Cl}(95 \%)$ & \\
\hline 1 & 5 & 1.6 & $0.6-3.8$ & 252 & 79.3 & $74.4-83.6$ & 61 & 19.2 & $15.1-24.0$ & 318 \\
\hline 2 & 3 & 1.0 & $0.3-3.1$ & 233 & 76.1 & $71.0-80.8$ & 70 & 22.9 & $18.4-28.1$ & 306 \\
\hline 3 & 4 & 1.2 & $0.4-3.3$ & 161 & 49.4 & $43.8-55.0$ & 161 & 49.4 & $43.8-55.0$ & 326 \\
\hline 4 & 2 & 0.6 & $0.1-2.5$ & 179 & 55.4 & $49.8-60.9$ & 142 & 44.0 & $38.5-49.6$ & 323 \\
\hline 5 & 9 & 2.8 & $1.4-5.5$ & 184 & 58.0 & $52.4-63.5$ & 124 & 39.1 & $33.8-44.7$ & 317 \\
\hline 6 & 0 & 0.0 & $0.0-1.6$ & 171 & 56.4 & $50.6-62.1$ & 132 & 43.6 & $37.9-49.4$ & 303 \\
\hline 7 & 2 & 0.7 & $0.1-2.6$ & 130 & 42.1 & $36.5-47.8$ & 177 & 57.3 & $51.6-62.9$ & 309 \\
\hline MG* & 25 & $1.4^{\mathrm{b}}$ & $0.8-1.9^{b}$ & 1310 & $59.8^{b}$ & $57.6-62.0^{b}$ & 867 & $38.9^{b}$ & $36.7-41.0^{b}$ & 2,202 \\
\hline
\end{tabular}

${ }^{\mathrm{a} C o n f i d e n c e ~ i n t e r v a l ; ~}{ }^{\mathrm{E} E f f e c t}$ of sample design: 1.306. Strata: 1 - Northwest, North and Northeast; 2 - East; 3 - Central; 4 - Zona da Mata; 5 - South and Southwest; 6 - Alto Paranaíba; 7 - Triângulo Mineiro

Also, with regard to the variable of the rearing system, the most used type in the state of Minas Gerais in 2002 was the extensive system (59.8\%), followed by the semi-confined system (38.9\%). Similar results were found by Belchior (2000) for the state of Minas Gerais in 1998/1999. Unlike the other strata, the region of Triângulo Mineiro mostly had farms that applied a semi-confined system (57.3\%). The confinement system was the least common type in the entire state, out of the whole sample (Table 3). Although most animals were reared within an extensive system, on the dairy farms, a noteworthy percentage of these cattle were subjected to a semi-confinement system (Figure 2A).

The region of Zona da Mata exhibited the highest percentage of dairy farms (Table 3 ), in which the extensive system was the most common rearing system (53.16\%). These findings were contrary to those reported by Belchior 
(2000) for 1998/1999, when this region was classified as an area of micro-producers of beef cattle. The difference in results may be related to differences in the classification system used by Belchior (2000).

The data analysis regarding beef exploitation demonstrated that the Triângulo Mineiro and Northwest, North and Northeast regions stood out regarding beef cattle production, compared to other strata (Figure 2B). In both regions, the predominant rearing system was the extensive system. The findings regarding Triângulo Mineiro were corroborated by data obtained from sampling performed in 1998/1999 in the same region (BELCHIOR, 2000), which classified this region as an area of micro-producers of beef cattle. From a sanitary perspective, considering the intense traffic of animals that is characteristic of beef cattle exploitation, the Triângulo Mineiro and Northwest, North and Northeast regions would be more susceptible to rapid dissemination of acute diseases, such as foot-and-mouth disease (CAETANO JÚNIOR, 2003), and chronic diseases such as brucellosis and tuberculosis. In this regard, control over this traffic has been addressed through a technical regulation issued by PNCEBT (BRASIL, 2006).

The data regarding the size of the herds on the farms sampled and the entire state in 2002 showed that the size ranged from 10 to 5,075 animals, with a median of 54 animals and mean of 114.8 (Table 4). These results were similar to those found by Belchior (2000), with a median of 50 and mean of 102 animals. Dairy farms presented smaller herds (median of 47) and lower variations, while beef farms had larger herds (median of 116) and also greater deviations in the median. These findings indicate that the dairy farms of the state of Minas Gerais have a more homogenous pattern than the beef cattle farms, regarding the size of their herds (Figure 3A).
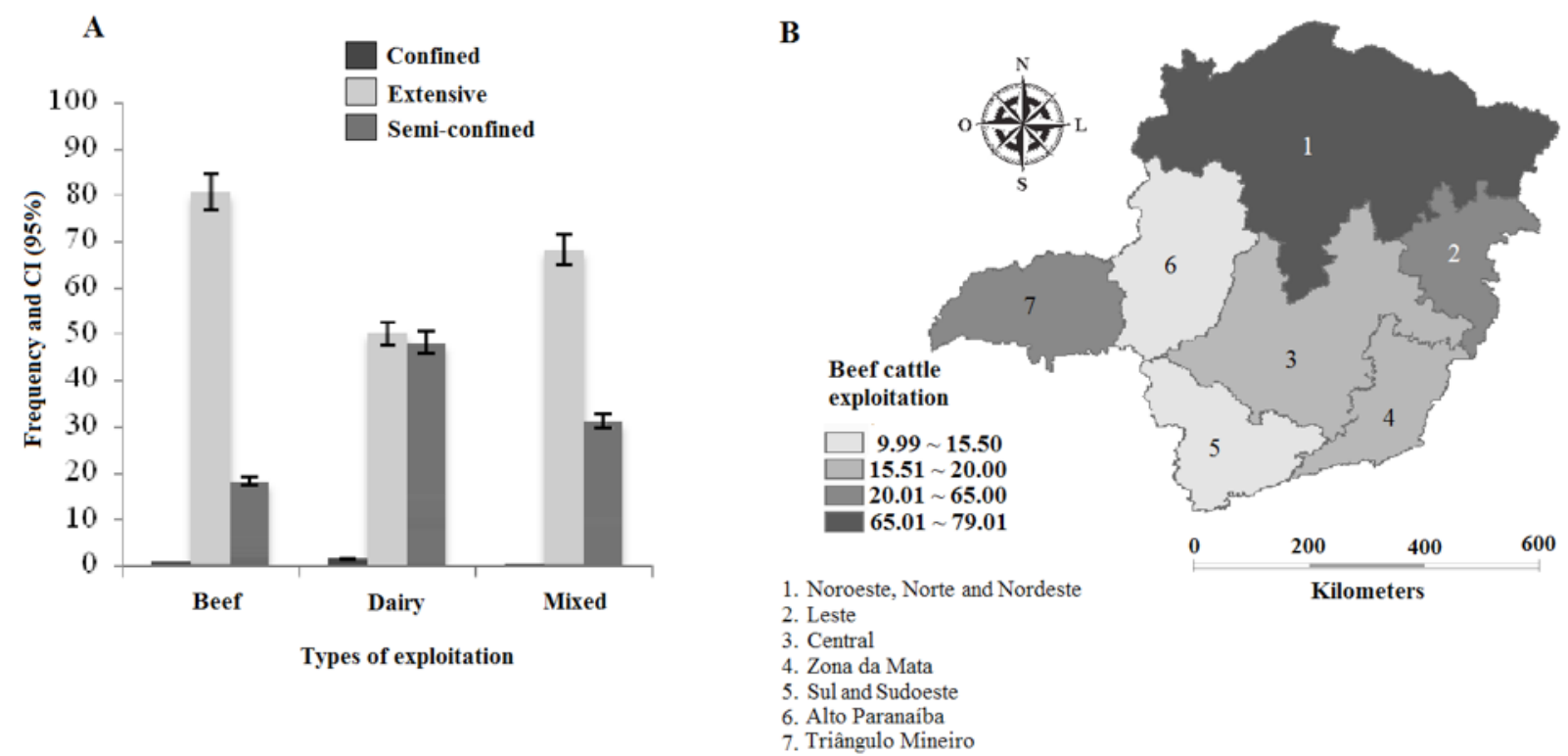

Figure 2 - (A) Percentage distribution of the rearing systems per type of cattle exploitation in Minas Gerais, 2002; (B) Distribution of beef cattle exploitation per strata in Minas Gerais, 2002 (category division: quartiles)

Table 4 - Size of the cattle herd per stratum in the state of Minas Gerais, 2002

\begin{tabular}{cccc}
\hline Strata & Median & Mean & $\begin{array}{c}\text { Standard } \\
\text { deviation }\end{array}$ \\
\hline 1 & 62.0 & 149.0 & 359.6 \\
2 & 69.0 & 135.4 & 217.2 \\
3 & 45.5 & 88.8 & 215.1 \\
4 & 31 & 53.51 & 83.4 \\
5 & 40.0 & 62.5 & 99.7 \\
6 & 66.5 & 99.2 & 151.8 \\
7 & 111.0 & 217.9 & 391.1 \\
MG & $\mathbf{5 4 . 0}$ & $\mathbf{1 1 4 . 8}$ & $\mathbf{2 4 9 . 3}$ \\
\hline
\end{tabular}

Strata: 1 - Northwest, North and Northeast; 2 - East; 3 - Central; 4 - Zona da Mata; 5 - South and Southwest; 6 - Alto Paranaíba; 7 - Triângulo Mineiro
Additionally, in agreement with what was observed by Belchior (2000), the region of Zona da Mata showed smaller herds (median of 31) and a more uniform distribution, thus indicating that this is a region where smaller farms predominate (Table 4, Figure 3B). On the contrary, the region of Triângulo Mineiro presented the largest herds in the sample, with considerable variation (Table 4). These deviations demonstrated there was less uniformity regarding the number of animals in each herd. This was due to the higher number of dairy and beef farms in this stratum, since dairy farms are commonly small, while beef farms are usually larger enterprises. 
A

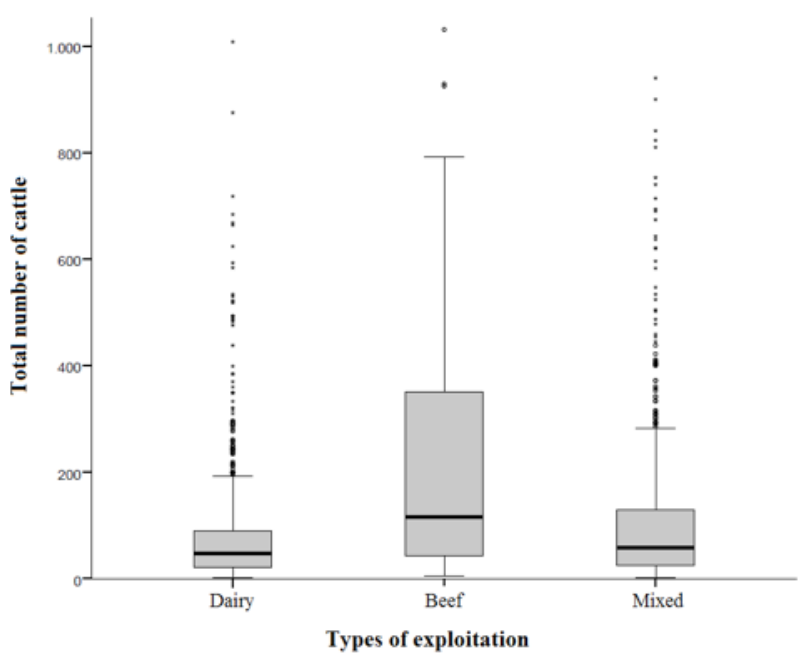

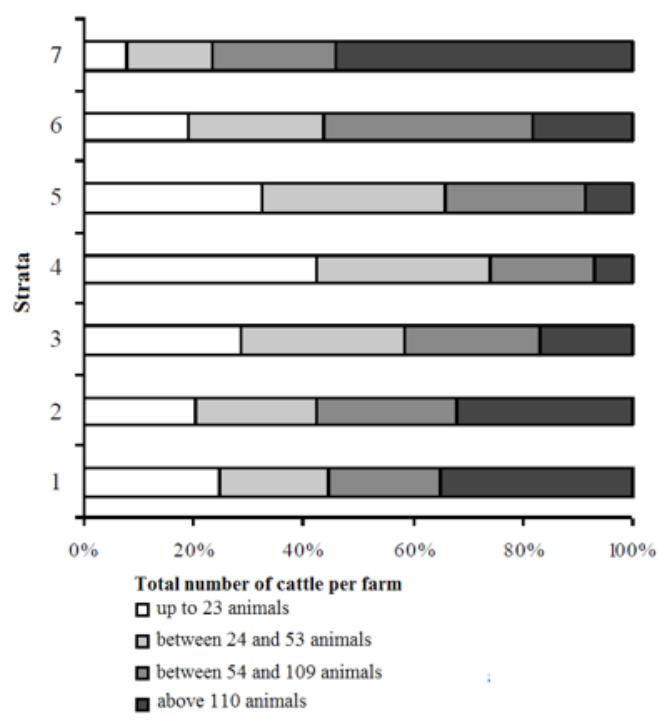

Figure 3 - (A) Total number of cattle per farm and per type of exploitation in Minas Gerais, 2002. Results are presented as boxplots (median and first and third quartiles). The symbols over the diagrams represent outliers; (B) Percentage distribution of the categories of the variable of total number of cattle per farm and per stratum in Minas Gerais, 2002

Moreover, it should be noted that the strata with higher number of beef cattle, i.e. the Northwest, North and Northeast and Triângulo Mineiro regions, also presented the largest herds (Table 4, Figure 3B). In contrast, the region of Zona da Mata, where dairy production is predominant, showed smaller herd size. These observations suggest a direct relationship between the size of the herd and type of exploitation (Figure 3A), which is valuable information for planning control and eradication actions or during sanitary emergencies

$\mathbf{A}$

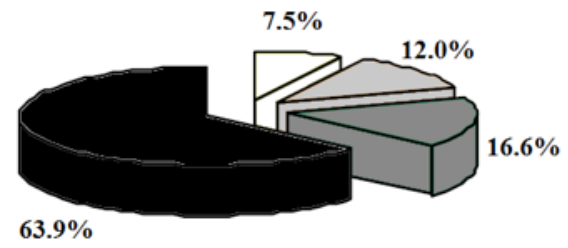

$\square$ Femeales up to 6 months

$\square$ Femeales between 6 and 12 months

$\square$ Femeales between 12 and 24 months

- Femeales above 24 months
Regarding the total number of animals in the herd, the analysis on different age groups among cows on each farm showed that the same distribution pattern repeats in all strata, reflecting the national pattern (Figure $4 \mathrm{~B}$ ). Considering the whole state, $63.9 \%$ of the total herd comprised cows over 24 months of age (Figure 4A). The explanation for this distribution is that this category forms the basis of the national cattle herd (FERREIRA NETO, 2009). Thus, data from this study clearly showed higher density of cows over 24 months of age, for the entire state and for each of the seven strata (Figure 4).
B

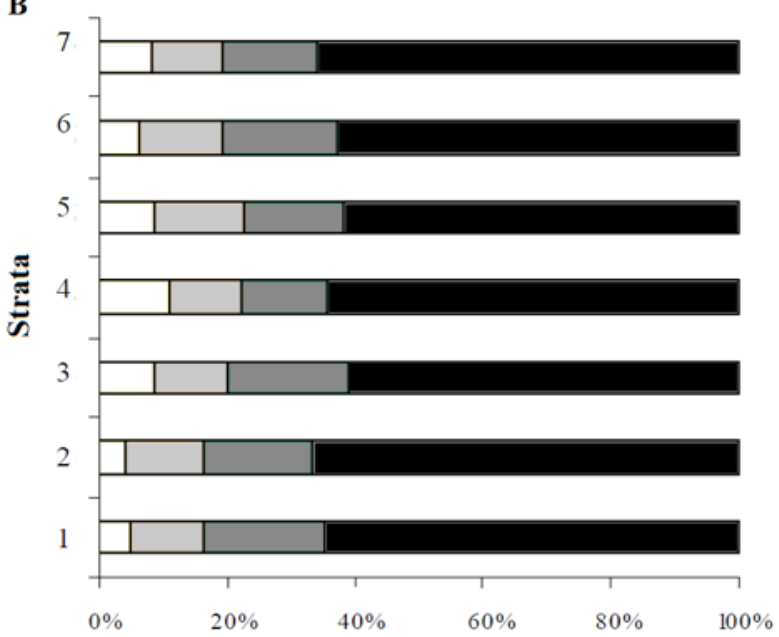

Figure 4 - (A) Percentage distribution of females per age group compared to the total in Minas Gerais, 2002; (B) Percentage distribution of females per age group and stratum in Minas Gerais, 2002

The large fraction of cows over 24 months of age in the herds, as observed in the state of Minas Gerais, was identified as an important risk factor for infectious diseases.
Regarding brucellosis, studies conducted in some regions of Brazil, such as the states of São Paulo (DIAS et al., 2009), Espírito Santo (AZEVEDO et al., 2009), Rondônia 
(FERREIRA NETO, 2009), the Federal District (MOTA, 2011), and in other countries such as Canada (KELLAR et al., 1976), Somalia (HUSSEIN et al., 1978), Tanzania (MSANGA et al., 1986) and Kenya (KADOHIRA et al., 1997) have shown a correlation of the number of cows over 24 months of age, and the total number of cattle, in the herd with a higher probability of the herd being a focus of the disease. Regarding brucellosis, this finding can be explained by a greater susceptibility to infection of sexually mature cattle, particularly pregnant cows (NICOLETTI, 1980; CRAWFORD et al., 1990). Thus, the higher the number of females of reproductive age in the herd, the higher the possibility of disseminating the disease. Moreover, a higher proportion of cows over 24 months of age in the herds sampled as compared to other age groups was also identified as a risk factor for tuberculosis (HOMEM, 2003; VELOSO, 2014), since older animals are more likely to have been exposed to the agent.

Unlike the results observed for different age groups of females, a wide variation between the strata was observed regarding the participation of males on these farms, compared to the whole herd, considering the five age groups assessed (Figure 5). Male animals above 24 months of age presented noteworthy participation (median $=19 \%$ ) in the composition of herds in the analysis for the entire state, similar to the situation observed for females above 24 months, which was considered to be a risk factor for diseases such as brucellosis and tuberculosis (HOMEM, 2003).

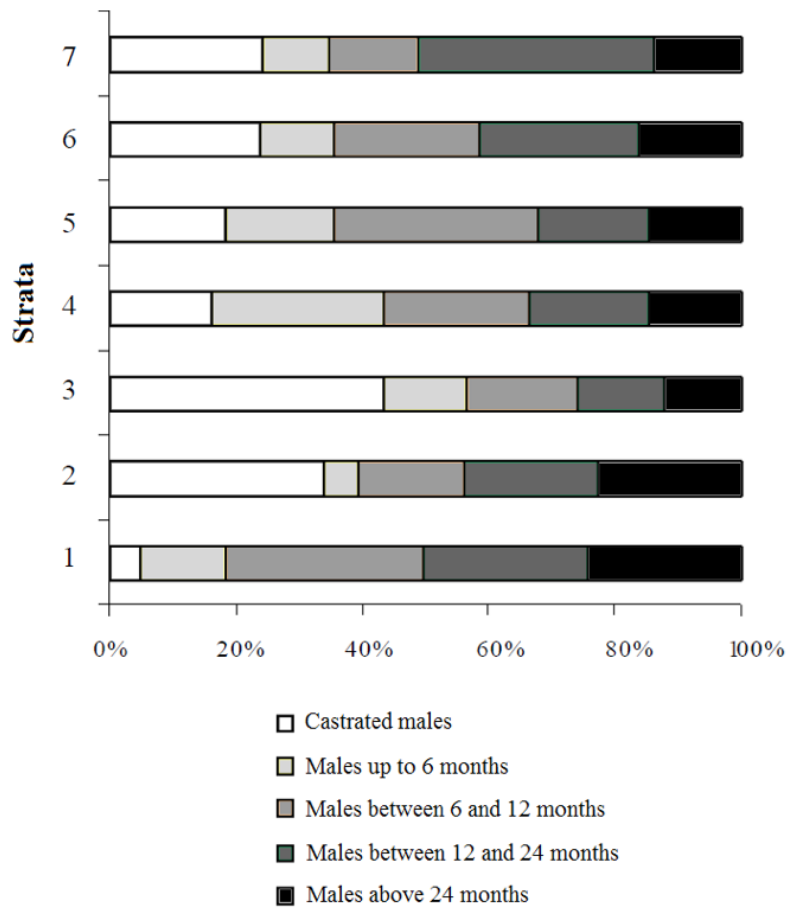

Figure 5 - Percentage distribution of males per category and stratum in Minas Gerais, 2002

Regarding the breeds used in cattle-rearing in Minas Gerais in 2002, the analyses suggested that neither the entire state $(71 \%)$ nor the seven strata in this study presented any defined pattern of breeds (Table 5). Similar results were found in the states of Paraíba (LEITE et al., 2004), Goiás (ROCHA, 2003), São Paulo (DIAS, 2004), Santa Catarina (SIKUSAWA, 2004), Espírito Santo (AZEVEDO, 2006) and Mato Grosso (NEGREIROS, 2006), which indicates that this is a predominant characteristic throughout Brazil.

Table 5 - Frequency of breeds per stratum in the state of Minas Gerais, 2002

\begin{tabular}{|c|c|c|c|c|c|c|c|c|c|c|}
\hline \multirow{2}{*}{ Strata } & \multicolumn{3}{|c|}{ Beef breeds } & \multicolumn{3}{|c|}{ Mixed breeds } & \multicolumn{3}{|c|}{ Dairy breeds } & \multirow{2}{*}{ Total } \\
\hline & $\mathbf{n}$ & $\%$ & $\mathrm{Cl}^{\mathrm{a}}(95 \%)$ & $\mathbf{n}$ & $\%$ & $\mathrm{Cl}(95 \%)$ & $\mathbf{n}$ & $\%$ & $\mathrm{Cl}(95 \%)$ & \\
\hline 1 & 73 & 23.0 & $18.5-28.1$ & 165 & 51.9 & $46.2-57.5$ & 80 & 25.2 & $20.6-30.4$ & 318 \\
\hline 2 & 14 & 4.6 & $2.6-7.7$ & 275 & 89.9 & $85.9-93.0$ & 17 & 5.6 & $3.4-8.9$ & 306 \\
\hline 3 & 8 & 2.5 & $1.1-5.0$ & 270 & 82.8 & $78.3-86.8$ & 48 & 14.7 & $11.2-19.1$ & 326 \\
\hline 4 & 5 & 1.5 & $0.6-3.8$ & 303 & 93.8 & $90.4-96.1$ & 15 & 4.6 & $2.7-7.7$ & 323 \\
\hline 5 & 6 & 1.9 & $0.8-4.3$ & 258 & 81.4 & $76.7-85.5$ & 53 & 16.7 & $12.9-21.4$ & 317 \\
\hline 6 & 13 & 4.3 & $2.4-7.4$ & 221 & 72.9 & $67.6-77.9$ & 69 & 22.8 & $18.3-28.0$ & 303 \\
\hline 7 & 39 & 12.6 & $9.2-17.0$ & 230 & 74.4 & $69.2-79.2$ & 40 & 12.9 & $9.5-17.3$ & 309 \\
\hline $\mathbf{M G}^{b}$ & 158 & $7.4^{b}$ & $6.2-8.5^{b}$ & 1,722 & $71.0^{b}$ & $75.2-78.8^{b}$ & 322 & $15.7^{b}$ & $14.0-17.3^{b}$ & 2,202 \\
\hline
\end{tabular}

a Confidence interval; ${ }^{\text {EEffect }}$ of sample design: 1.081. Strata: 1 - Northwest, North and Northeast; 2 - East; 3 - Central; 4 - Zona da Mata; 5 - South and Southwest; 6 - Alto Paranaíba; 7 - Triângulo Mineiro

Specialized breeds for dairy and beef production were less frequent on the farms sampled, considering both the whole state and the different strata (Table 5). Beef cattle producers were more specialized, considering that $68.3 \%$ of the farms presented specialized beef breeds in their herds. This was not observed in dairy and mixed farms, of which $82.15 \%$ and $85.60 \%$ showed mixed-breed cattle, respectively. In a study conducted in part of the state of 
Minas Gerais between 1998 and 1999, Belchior (2000) observed that beef producers (45\%) presented specialized breeds in their herds, while only $8.3 \%$ of dairy herds were constituted exclusively of dairy breeds. This author explained these findings based on the higher level of professionalization of beef producers compared to dairy producers, given the national milk policy. This hypothesis was highlighted by França (2006), who affirmed that low incorporation of technology, some environmental factors of importance for milk production, high production costs and low earnings for milk would all explain the use of mixed breeds instead of specialized ones. Other authors mentioned that choosing to use mixed-breed cattle was associated with lower nutritional requirements and greater adaptation to climatic and topographic conditions, and to the animal rearing system itself, thereby maintaining good productivity with relatively low costs, compared to specialized cattle (GOMES, 1996; MORAES et al., 2004).

In agreement with the low level of specialization of the cattle in Minas Gerais and the high dairy production activity in this state, the analysis on reproductive management variables showed that the use of artificial insemination was minimal, such that $89.4 \%$ of the farms were using the natural mating system (Table 6). These results are slightly above the national mean, which is an artificial insemination rate of below 5\% (FONSECA, 2000). However, this rate is very low if compared with countries such as Israel (99\% of females at reproductive age), New Zealand (90\%) and the United States (65\%). According to Chenoweth and Larsen (1992), the preference for using natural mating is due to the lower costs, relative to the inherent costs of artificial insemination, and to the lack of personnel with adequate training and motivation for success in this technique. This lack of personnel compromises the results especially through negligence in detecting the time when cows are in heat.

This situation did not change in assessing the different strata. Natural mating remained the most common reproduction method, used on over $85 \%$ of the farms (Table 6). As expected, the Northwest, North and Northeast regions, which had the largest number of bulls, used natural mating most frequently, while the region of Zona da Mata, which presented the lowest number of bulls, used artificial insemination most frequently (Table 6 and Figure 5).

Table 6 - Frequency of types of reproductive management per stratum in the state of Minas Gerais, 2002

\begin{tabular}{|c|c|c|c|c|c|c|c|c|c|c|}
\hline \multirow{2}{*}{ Strata } & \multicolumn{3}{|c|}{ Natural mating } & \multicolumn{3}{|c|}{$\mathbf{A} \mathbf{l}^{\mathbf{b}}+$ natural mating } & \multicolumn{3}{|c|}{ Al } & \multirow{2}{*}{ Total } \\
\hline & $\mathbf{n}$ & $\%$ & $\mathrm{Cl}^{\mathrm{a}}(95 \%)$ & $\mathbf{n}$ & $\%$ & $\mathrm{Cl}(95 \%)$ & $\mathbf{n}$ & $\%$ & $\mathrm{Cl}(95 \%)$ & \\
\hline 1 & 296 & 93.1 & $89.6-95.5$ & 11 & 3.5 & $1.8-6.3$ & 11 & 3.5 & $1.8-6.3$ & 318 \\
\hline 2 & 278 & 90.9 & $87.0-93.8$ & 22 & 7.2 & $4.7-10.8$ & 6 & 2.0 & $0.8-4.4$ & 306 \\
\hline 3 & 281 & 86.2 & $82.0-89.8$ & 32 & 9.8 & $6.9-13.7$ & 13 & 4.0 & $2.2-6.9$ & 326 \\
\hline 4 & 281 & 87.0 & $82.8-90.5$ & 24 & 7.4 & $4.9-11.0$ & 18 & 5.6 & $3.4-8.8$ & 323 \\
\hline 5 & 291 & 91.8 & $88.2-94.6$ & 15 & 4.7 & $2.8-7.9$ & 11 & 3.5 & $1.8-6.3$ & 317 \\
\hline 6 & 264 & 87.1 & $82.8-90.7$ & 16 & 5.3 & $3.1-8.6$ & 23 & 7.6 & $5.0-11.3$ & 303 \\
\hline 7 & 276 & 89.3 & $85.3-92.5$ & 20 & 6.5 & $4.1-10.0$ & 13 & 4.2 & $2.4-7.3$ & 309 \\
\hline MG & 1,967 & $89.4^{c}$ & $87.9-90.8^{c}$ & 140 & $6.5^{c}$ & $5.3-7.6^{c}$ & 95 & $4.2^{c}$ & $3.3-5.1^{c}$ & 2,202 \\
\hline
\end{tabular}

${ }^{\mathrm{a} C o n f i d e n c e ~ i n t e r v a l ;}{ }^{\mathrm{b}}$ Artificial insemination; ${ }^{\mathrm{c} E f f e c t}$ of sample design: 1.189. Strata: 1 - Northwest, North and Northeast; 2 - East; 3 - Central; 4 - Zona da Mata; 5 - South and Southwest; 6 - Alto Paranaíba; 7 - Triângulo Mineiro

The choice of natural mating was also repeated among the various forms of exploitation. The highest percentage of this type of reproductive management strategy was observed on farms that used mixed exploitation (94.2\%), followed by beef exploitation (91.5\%). Despite their low rates, dairy farms used artificial insemination most frequently, either together with natural breeding $(7.8 \%)$ or alone $(6.3 \%)$. This was because dairy cattle management is more direct, such that these farmers measure the production of their cows on a daily basis, which aids in detecting the time when they are in heat. Regarding rearing systems, farms under an extensive system used natural mating more frequently (94.4\%), as expected. Farms that confine the cattle used mostly artificial insemination, either alone (20\%) or with natural breeding (16\%), since animal management is easier.

As previously reported for the proportion of females over 24 months in the herd, artificial insemination was also considered a risk factor for bovine brucellosis by Dias et al. (2009), in a study conducted in the state of 
São Paulo, and by Azevedo et al. (2009) in Espírito Santo. Artificial insemination using semen from infected bulls gives rise to the risk of brucellosis transmission, as well as other infectious diseases, because the semen is deposited directly within the uterus, possibly infecting the female with small amounts of the agent (ACHA; SZYFRES, 2001; PAULIN; FERREIRA NETO, 2003). However, it is worth mentioning that, provided that artificial insemination is performed using semen that originates from insemination centers following international norms and are registered at MAPA, or that sanitary control over the herd is maintained and semen is adequately processed, this is a consolidated and safe assisted reproduction method that enables faster genetic improvement in cattle herds (ASBIA, 2006).

Dairy livestock-rearing has great importance in the state of Minas Gerais. Thus, analyses were performed

A

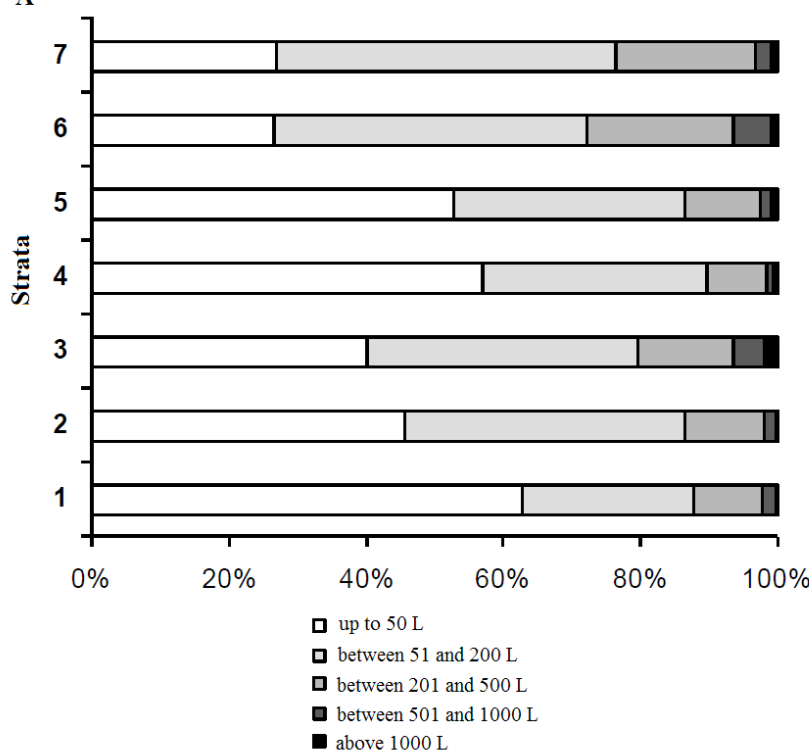

specifically to characterize the production of farms that are directly involved in dairy production, meaning either dairy or mixed farms. Based on the dairy production data of the sample studied, the median was $70 \mathrm{~L} /$ day. The region of Alto Paranaíba presented the highest daily production of milk in liters (median $=120 \mathrm{~L} /$ day), followed by the region of Triângulo Mineiro (median $=90 \mathrm{~L} /$ day). Analysis on the number of lactating cows also showed that these regions had the highest medians: 19 and 21 head of cattle, respectively. These results are in agreement with the data provided by Gomes (2006), who reported that these two regions had the largest participations of dairy production in the state, with $22.5 \%$ in 1995 and $24.83 \%$ in 2005 . On the other hand, the Northwest, North and Northeast regions presented the lowest production in the state (median $=40$ L/day) (Figure 6).

B

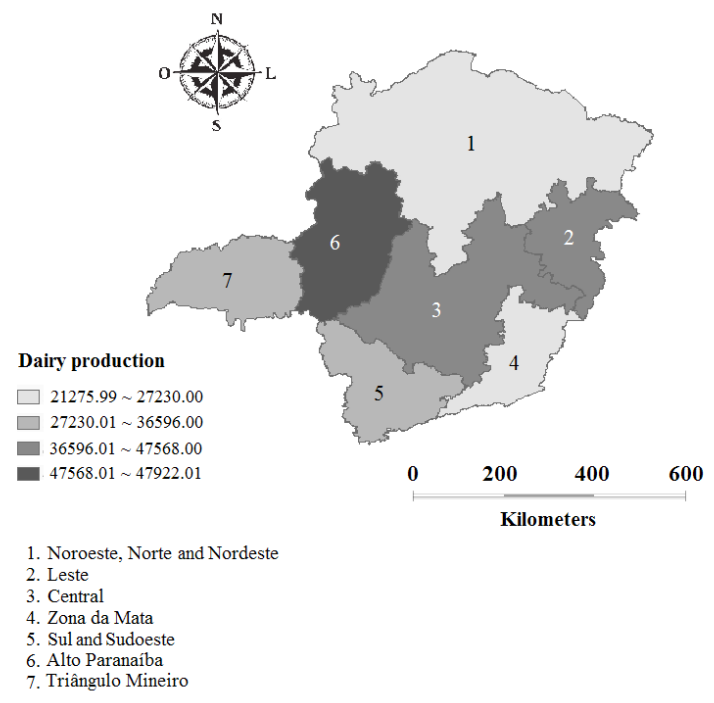

Figure 6 - (A) Percentage distribution of farms per range of dairy production and stratum in Minas Gerais, 2002; (B) Distribution of dairy production in each stratum in Minas Gerais, 2002 (category division: quartiles)

Daily milk productivity per lactating cow for the whole state was low, with a median of $5.0 \mathrm{~L} / \mathrm{cow} /$ day. This showed that there was low specialization of milk production in Minas Gerais. Ferrão (2000) and França (2006) found a mean daily production per cow higher than what was observed in the present study: $12.7 \mathrm{~L}$ and $10.5 \mathrm{~L} /$ cow/ day, respectively. However, those studies used different sampling methods and were restricted to specific regions in Minas Gerais: Esmeraldas/Sete Lagoas and Pedro Leopoldo, respectively.

The region of Alto Paranaíba presented the highest daily milk productivity rates per lactating cow (median of 6.0
L/cow/day), while the Northwest, North and Northeast regions presented the lowest (median of $2.0 \mathrm{~L} / \mathrm{cow} /$ day). These findings were in agreement with the data by Gomes (2006), who observed that the Northwest, North and Northeast and Jequitinhonha regions had the worst productivity performance, thus characterizing them as the least specialized regions regarding dairy production. In a study conducted by Bandeira (2001), the regions of Triângulo Mineiro and Alto Paranaíba stood out as the main dairy producers, thus possessing a significant advantage over the others, according to BDMG (2002). These regions used a business livestock-rearing model, with intensive use 
of technology and modern management systems. These data are also in agreement with the evaluation by Gomes (2006), which demonstrated that Brazilian dairy production is moving to the Cerrado biome, seeking low production costs and the existence of an industrial framework for inputs and processing of livestock production.

Regarding production capacity, the data from the present study revealed that the state is mostly constituted by farms producing up to $50.0 \mathrm{~L} /$ day $(44.6 \%)$ and contributing $7.3 \%$ of the national production. Those that produce more than $1,000 \mathrm{~L} /$ day only represent $0.9 \%$ of the farms, but contribute with $19.1 \%$ of milk production (Figure 7). The region of Zona da Mata presented one of the highest numbers of small producers (up to $50 \mathrm{~L}$ ), while the regions of Alto Paranaíba and Triângulo Mineiro presented the lowest percentage of farms in the class of lowest dairy production (Figure 6). Therefore, although the region of Zona da Mata presented a high number of dairy farms, this region is not very specialized and is characterized by low dairy production and productivity.

B

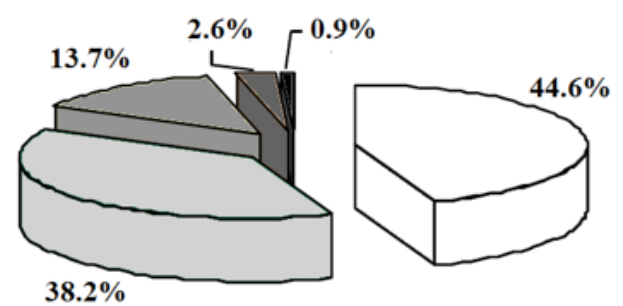

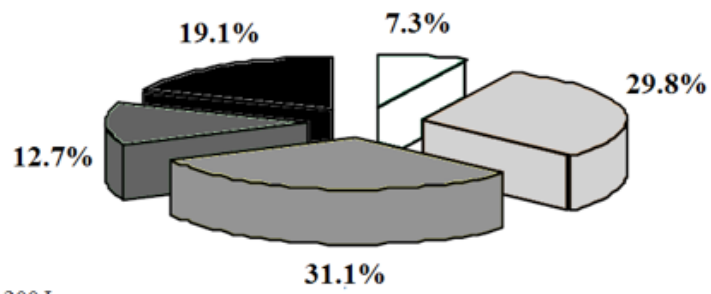

$31.1 \%$

$\square$ between 51 and $200 \mathrm{~L}$

$\square$ between 201 and $500 \mathrm{~L}$

between 501 and $1000 \mathrm{~L}$

above $1000 \mathrm{~L}$

Figure 7 - (A) Percentage distribution of farms per dairy production band in Minas Gerais, 2002; (B) Percentage distribution of dairy production per production band in Minas Gerais, 2002

The highest production volume originated from farms that produced between $50 \mathrm{~L}$ and $500 \mathrm{~L} /$ day, representing $60.9 \%$ of the production of the state (Figure 7). These findings are in accordance with those of Gomes (2006), who observed that farms with these ranges of production accounted for $69.6 \%$ of the total dairy production of the state. Thus, dairy production in the state of Minas Gerais is concentrated among only a few producers that are within the ranges of highest production.

By comparing the different ranges of dairy production with the variables of rearing systems, specialized breed and frequency and type of milking, a clearly increasing trend towards specialization was observed, from the smallest to the largest producers (Figure 8 ). These results confirm the information provided by Gomes (2006) that technological duality is a characteristic that stands out in the dairy production of Brazil and Minas Gerais. This can be observed in the coexistence of producers that use high technology and reach high rates of productivity and traditional producers that use low technology and reach lower productivity levels.

Studies conducted in 1997 on farms linked to the Central Cooperative of Rural Producers of Minas Gerais
(Itambé) indicated that most producers only milked their cattle once a day, manually and in the presence of the calf (MADALENA et al., 1997). The data of the present study confirmed these findings, since $67 \%$ of the farms sampled in the state of Minas Gerais reported milking the cattle only once per day. The region of Alto Paranaíba stood out with its relatively high number of farms that performed milking twice a day (48.9\%), which emphasizes that dairy production has become more notable in this region (GOMES, 2006).

In the whole state of Minas Gerais and in all strata, cattle are still milked manually on most farms (90\%). This was also observed by Belchior (2000) for part of this state, and by Rocha (2003) in Goiás, Sikusawa (2004) in Santa Catarina and Azevedo (2006) in Espírito Santo. On the other hand, mechanical milking was most prevalent in the states of Paraná (DIAS, 2003) and São Paulo (DIAS, 2004).

According to Gomes (2006), between the years of 1995 and 2005, there was significant growth in the use of mechanical milking in Minas Gerais. Its prevalence went from $4.5 \%$ to $17.2 \%$, with particular emphasis in the 
Central, Northwestern, Campo das Vertentes and Belo Horizonte metropolitan regions. In the present study, the use of mechanical milking did not surpass $10 \%$ in the whole state. It should be noted that the data of the present study were gathered in 2002 , i.e. within the interval of the studies by Gomes (1996; 2006), and presented intermediate values, thus demonstrating that there was a gradual increase in the use of mechanical milking. However, the sampling for these studies was performed differently. Thus, periodical analyses and revalidations are required, as reported by Zotelle and Astudillo (1992), who indicated that agricultural and livestock-rearing scenarios need to be defined and revised periodically so as to be able to make adjustments to plans as situations develop.
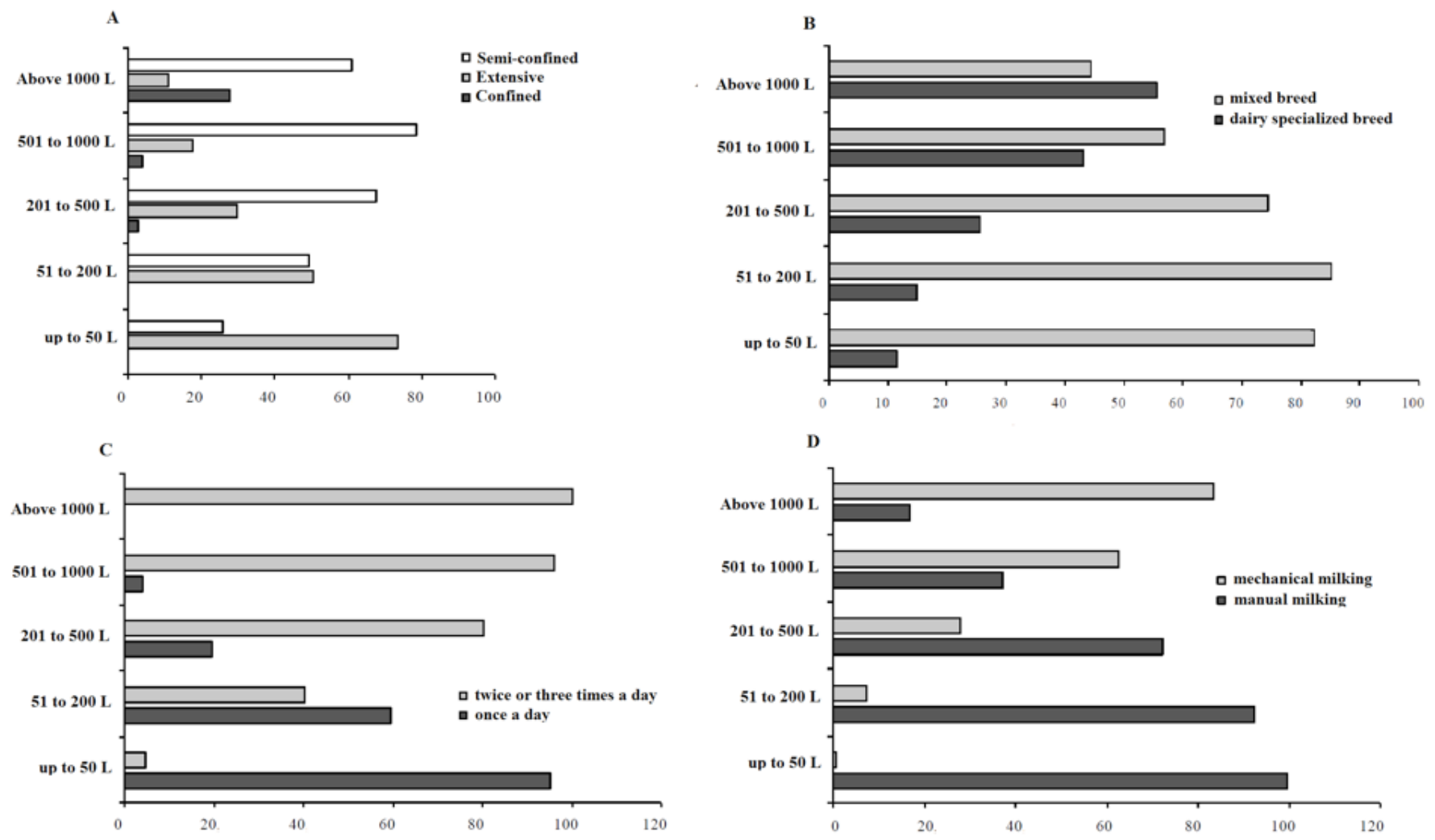

Figure 8 - (A) Percentage distribution of the number of farms according to their dairy production band, per rearing system, in Minas Gerais, 2002; (B) Percentage distribution of the number of dairy and mixed farms, according to their dairy production band, per breed (specialized for milk and mixed), in Minas Gerais, 2002; (C) Percentage distribution of the number of farms according to their dairy production band, and according to milking frequency, in Minas Gerais, 2002. (D) Percentage distribution of farms according to their dairy production band and type of milking in Minas Gerais, 2002

\section{Conclusions}

This study demonstrated great heterogeneity among strata regarding types of exploitation, types of rearing, herd size, specialization and dairy production. This validates the stratification established by MAPA and suggests that it should be maintained for future epidemiological studies. Cattle herds in Minas Gerais are still not commonly specialized. The region of Triângulo Mineiro was considered to be the one that was most technologically advanced and had the greatest importance regarding beef cattle, together with the Northwest, North and Northeast regions. The region of Zona da Mata was considered to be the one that was least technologically advanced and constituted by the smallest farms. Dairy production in the state is distributed among all strata, but is concentrated among a few highly productive farms, particularly in the region of Alto Paranaíba.

\section{Conflict of interest}

The authors declare that they have no conflict of interest.

\section{Acknowledgements}

This study was funded by the Research Support Foundation of the State of Minas Gerais (Fapemig) (Belo Horizonte, Brazil), FEP-MVZ Preventive Coordination (Belo Horizonte, Brazil) and the National Council for Scientific and Technological Development (CNPq) (Brasília, Brazil). EMSD and APL were supported with grants from CNPq. 


\section{References}

ACHA, P. N.; SZYFRES, B. Zoonosis y enfermedades transmisibles comunes al hombre y a los animales. 3 . ed. Washington: Organización Panamericana de la Salud, 2001. 398 p.

\section{ASSOCIAÇÃO BRASILEIRA DE INSEMINAÇÃO} ARTIFICIAL. Informações sobre inseminação artificial. Uberaba: Asbia, 2006. Available from: <http://www.asbia.org. br/artigos/inseminacao-artificial/>. Viewed: Nov. 22th, 2012.

AZEVEDO, S. S. Caracterização epidemiológica da brucelose bovina no estado do Espírito Santo. 2006. $103 \mathrm{f}$. Tese (Doutorado em Medicina Veterinária) - Faculdade de Medicina Veterinária e Zootecnia, Universidade de São Paulo, São Paulo, 2006.

AZEVEDO, S. S.; FERREIRA NETO, J. S.; DIAS, R. A.; FERREIRA, F.; AMAKU, M.; FIGUEIREDO, V. C. F.; LÔBO, J. R.; GONÇALVES, V. S. P.; SOUZA, A. C.; VASCONCELLOS, S. A. Situação epidemiológica da brucelose bovina no estado do Espírito Santo. Arquivo Brasileiro de Medicina Veterinária e Zootecnia, v. 61 , p. 19-26, 2009. Supplement 1. doi: 10.1590/S010209352009000700004 .

\section{BANCO DO ESTADO DE MINAS GERAIS. Minas Gerais} do Século XXI: transformando o desenvolvimento da agropecuária. Belo Horizonte: BDMG, 2002.244 p. Available from: <http://intranet.uemg.br/comunicacao/arquivos/MGXXI-Volume\%20I.pdf>. Viewed: Dec. 20th, 2008.

BANDEIRA, A. A. Melhoria da qualidade e a modernização da pecuária leiteira nacional. In: GOMES A. T.; LEITE J. L.; CARNEIRO A. V. (ed.). O agronegócio do leite no Brasil. Juiz de fora: Embrapa Gado de Leite, 2001. p. 89-100.

BELCHIOR, A. P. C. Prevalência, distribuição regional e fatores de risco da tuberculose bovina em Minas Gerais. 2000. 55 f. Dissertação (Mestrado em Medicina Veterinária Preventiva e Epidemiologia) - Escola de Veterinária, Universidade Federal de Minas Gerais, Belo Horizonte, 2000.

BRASIL. Manual técnico do Programa Nacional de Controle e Erradicação da Brucelose e da Tuberculose Animal. Brasília, DF: Ministério da Agricultura, Pecuária e Abastecimento, 2006. 188 p.
CAETANO JÚNIOR, J. Risco de febre aftosa associado ao transito de bovinos no Triângulo Mineiro, Minas Gerais, Brasil. 2003. 101 f. Tese (Doutorado em Medicina Veterinária Preventiva e Epidemiologia) - Escola de Veterinária, Universidade Federal de Minas Gerais, Belo Horizonte, 2003.

CHENOWETH, P. J.; LARSEN, R. E. Selection, use and management of natural service bulls. In: VAN HORN, H. H.; WILCOX, C. J. Large dairy herd management. Champaign: American Dairy Science Association, 1992. p. 209-218.

CRAWFORD, R. P.; HUBER, J. D.; ADAMS, B. S. Epidemiology and surveillance. In: NIELSEN, K.; DUNCAN, J. R. Animal brucellosis. Boca Raton: CRC Press, 1990. p. 131-151.

DIAS, J. A. Soroepidemiologia da brucelose bovina e bubalina no estado do Paraná. 2003. 41 f. Dissertação (Mestrado em Medicina Veterinária) - Centro de Ciências Agrárias, Universidade Estadual de Londrina, Londrina, 2003.

DIAS, R. A. Caracterização espacial da brucelose bovina no estado de São Paulo. 2004. 112 f. Tese (Doutorado em Medicina Veterinária) - Faculdade de Medicina Veterinária e Zootecnia, Universidade de São Paulo, São Paulo, 2004.

DIAS, R. A.; GONÇALVES, V. S. P.; FIGUEIREDO, V. C. F.; LÔBO, J. R.; LIMA, Z. M. B.; PAULIN, L. M. S.; GUNNEWIEK, M. F. K.; AMAKU, M.; FERREIRA NETO, J. S.; FERREIRA, F. Situação epidemiológica da brucelose bovina no estado de São Paulo. Arquivo Brasileiro de Medicina Veterinária e Zootecnia, v. 61, p. 118-125, 2009. Supplement 1. doi: 10.1590/S0102-09352009000700015.

FERRÃO, I. S. A produção de leite e o profissional veterinário na percepção de produtores de leite de Pedro Leopoldo - MG, 1999. 2000. 47 p. Dissertação (Mestrado em Medicina Veterinária Preventiva) - Escola de Veterinária, Universidade Federal de Minas Gerais, Belo Horizonte, 2000.

FERREIRA NETO, J. S. Situação epidemiológica da brucelose bovina no Brasil: bases para as intervenções. 
Revista Ciência Animal Brasileira, p. 1-16, 2009. Supplement 1. Available from: <https://www.revistas.ufg. br/vet/article/view/7669>. Dec. 13th, 2018.

FNP. Anualpec: Anuário da Pecuária Brasileira 2014. São Paulo: FNP, 2014. 368 p.

FONSECA, V. O. O touro no contexto da eficiência reprodutiva do rebanho. Informe Agropecuário, v. 21, n. 205, p. 48-63, 2000.

FRANÇA, S. R. A. Perfil dos produtores, características das propriedades, e qualidade doleite bovino nos municípios de Esmeraldas e Sete Lagoas-MG. 2006. 108 p. Tese (Doutorado em Ciência Animal) - Escola de Veterinária, Universidade Federal de Minas Gerais, Belo Horizonte, 2006.

GOMES, S. T. A economia do leite: Coronel Pacheco, MG. Juiz de Fora: Embrapa Gado de Leite, 1996. 98 p.

GOMES, S. T. Diagnóstico da pecuária leiteira do estado de Minas Gerais em 2005: relatório de pesquisa. Belo Horizonte: Faemg, 2006. 156 p.

GONÇALVES, V. S. P.; DELPHINO, M. K. V. C.; DIAS, R. A.; FERREIRA, F.; AMAKU, M.; FERREIRA NETO, J. S.; PORTO, T. B.; ALVES, C. M.; FIGUEIREDO, V. C. F.; LÔBO, J. R. Situação epidemiológica da brucelose bovina no estado de Minas Gerais. Arquivo Brasileiro de Medicina Veterinária e Zootecnia, v. 61, p. 35-45, 2009. Supplement 1. doi: 10.1590/S0102-09352009000700006.

HOMEM, V. S. F. Brucelose e tuberculose bovinas no município de Pirassununga, SP: prevalências, fatores de risco e estudo econômico. 2003. 112 f. Tese (Doutorado em Medicina Veterinária) - Faculdade de Medicina Veterinária e Zootecnia, Universidade de São Paulo, São Paulo, 2003.

HUSSEIN, A. S.; SINGH, S. S.; HAJI, H. A survey of bovine brucellosis in the southern parts of Somalia Democratic Republic. Bulletin of Animal Health and Production in Africa, v. 26, n. 2, p. 150-153, 1978.

INSTITUTO BRASILEIRO DE GEOGRAFIA E ESTATÍSTICA. Censo demográfico 2010. Rio de Janeiro: IBGE, 2010. Available from: <https://biblioteca.ibge.gov. br/visualizacao/periodicos/93/cd_2010_caracteristicas_ populacao_domicilios.pdf>. Viewed: Jun. 3, 2014.

INSTITUTO BRASILEIRO DE GEOGRAFIA E ESTATÍsTICA. Produção da Pecuária Municipal. Rio de Janeiro: IBGE, 2011. v. 39. Available from: <ftp://ftp. ibge.gov.br/Producao_Pecuaria/Producao_da_Pecuaria_ Municipal/2011/ppm2011.pdf>. Viewed: Jun. 3, 2014.

INSTITUTO BRASILEIRO DE GEOGRAFIA E ESTATÍSTICA. Produção da pecuária municipal. Rio de Janeiro: IBGE, 2012a. v. 40. Available from: <ftp://ftp. ibge.gov.br/Producao_Pecuaria/Producao_da_Pecuaria_ Municipal/2012/ppm2012.pdf>. Viewed: Aug. 24th, 2014.

INSTITUTO BRASILEIRO DE GEOGRAFIA E ESTATÍSTICA. Síntese de Indicadores Sociais: uma análise das condições de vida da população brasileira. Rio de Janeiro: IBGE, 2012b. Available from: <https://ww2. ibge.gov.br/home/estatistica/populacao/condicaodevida/ indicadoresminimos/sinteseindicsociais2012/default. shtm>. Viewed: Aug. 24th, 2014.

KADOHIRA, M.; MCDERMOTT, J. J.; SHOUKRI, M. M.; KYULE, M. N. Variations in the prevalence of antibody to Brucella infection in cattle by farm, area and district in Kenya. Epidemiology and Infection, v. 118, n. 1, p. 35-41, 1997. Available from: <https://www.ncbi.nlm.nih.gov/pmc/ articles/PMC2808770/pdf/9042033.pdf>. Viewed: Dec. 13th, 2018.

KELLAR,J.;MARRA, R.;MARTIN, W. Brucellosis in Ontario: a case control study. Canadian Journal of Comparative Medicine, v. 40, n. 2, p. 119-128, 1976. Available from: <https:// www.ncbi.nlm.nih.gov/pmc/articles/PMC1277534/pdf/ compmed00038-0005.pdf $>$. Viewed: Dec. 13th, 2018.

LEITE, R. H. M.; LAGE, A. P.; JAYME, V. S.; MODENA, C. M. Perfil produtivo-sanitário de propriedades produtoras de bovinos do estado da Paraíba, Brasil. Ciência Animal Brasileira, v. 5, n. 4, p. 199-209, 2004. Available from: <https://www.revistas.ufg.br/vet/article/ view/26839/15359>. Viewed: Dec. 13th, 2018.

MADALENA, F. E.; ABREU, F. E.; SAMPAIO, I. B. M.; FERREIRA SOBRINHO, F. Práticas de cruzamentos em fazendas leiteiras afiliadas à Cooperativa Central de 
Produtores Rurais de Minas Gerais. Revista Brasileira de Zootecnia, v. 26, n. 5, p. 924-934, 1997. Available from: $<$ http://www.fernandomadalena.com/site_arquivos/041. pdf $>$. Viewed: Dec. 13th, 2018.

MORAES, A. C. A.; COELHO, S. G.; RUAS, J. R. M.; RIBEIRO, J. C. V. C.; VIEIRA, F. A. P.; MENEZES, A. C. Estudo técnico e econômico de um sistema de produção de leite com gado mestiço F1 Holandês-Zebu. Arquivo Brasileiro de Medicina Veterinária e Zootecnia, v. 56, n. 6, p. 745-749, 2004. doi: 10.1590/S0102-09352004000600008.

MOTA, A. L. A. A. Fatores de risco para a brucelose bovina no Brasil. 2011. 73 f. Dissertação (Mestrado em Saúde Animal) - Faculdade de Agronomia e Medicina Veterinária, Universidade de Brasília, Brasília, DF, 2011.

MSANGA, J. F.; MUKANGI, D. J. A.; TUNGARAZA, R. Bovine brucellosis in the lake zone of Tanzania: the present situation. Bulletin of Animal Health and Production in Africa, v. 34, p. 230-234, 1986.

NEGREIROS, R. L. Caracterização da brucelose bovina no estado do Mato Grosso. 2006. $104 \mathrm{f}$. Dissertação (Mestrado em Epidemiologia Experimental e Aplicada às Zoonoses) - Faculdade de Medicina Veterinária e Zootecnia, Universidade de São Paulo, São Paulo, SP, 2006.

NICOLETTI, P. The epidemiology of bovine brucellosis. Advances in Veterinary Science and Comparative Medicine, v. 24, p. 69-98, 1980.

NOORDHUIZEN, J. P. T. M.; FRANKENA, K.; VAN DER HOOFD, C. M.; GRAAT, E. A. M. Application of quantitative methods in veterinary epidemiology. Wageningen: Wagenigen Press, 1997. 445 p.

PAULIN, L. M.; FERREIRA NETO, J. S. A experiência brasileira no combate à brucelose bovina. Jaboticabal: Funep, 2003. 154 p.

ROCHA, W. V. Soroprevalência, distribuição regional e fatores de risco da brucelose em fêmeas bovinas adultas no estado de Goiás. 2003. 63 f. Dissertação (Mestrado em Medicina Veterinária) - Escola de Veterinária, Universidade Federal de Goiás, Goiânia, 2003.

SIEGEL, S. Estatística não-paramétrica para as ciências do comportamento. São Paulo: McGraw-Hill, 1975. 350 p.

SIKUSAWA, S. Prevalência e caracterização epidemiológica da brucelose bovina no estado de Santa Catarina. 2004. 107 f. Dissertação (Mestrado em Medicina Veterinária) - Faculdade de Medicina Veterinária e Zootecnia, Universidade de São Paulo, São Paulo, 2004.

VELOSO, F. P. Prevalência e fatores de risco da tuberculose bovina no estado de Santa Catarina. 2014. 31 f. Dissertação (Mestrado em Saúde Animal) - Faculdade de Agronomia e Medicina Veterinária, Universidade de Brasília, Brasília, DF, 2014.

ZAR, J. H. Biostatistical analysis. 3 ed. New Jersey: Prentice Hall, 1999. 613 p.

ZOTELlE, A. C.; ASTUDillO, V. M. Economía de la salud animal, desarrollo económico y control gerencial a nivel local. Rio de Janeiro: Centro Panamericano de Fiebre Aftosa, 1992. 10 p. 